\title{
The 'long now' of southern African water: Exploring aspects of enchantment and disenchantment in Brandfort
}

\author{
JTEMPELHOFF
}

\begin{abstract}
Strategies aimed at understanding contemporary South African water supply and sanitation problems require a broad view of factors such as migration, urbanisation and climate change. Working from a case study of the water supply of the town of Brandfort in the Free State Province of South Africa, attention is given to its contemporary water crisis; the origins of the town in the nineteenth century; a view of the deep time of the region; and suggestions for gaining understanding of the town's contemporary social ecological history in terms of the dynamics of its local water supplies.
\end{abstract}

Keywords: Brandfort; Erfenis Dam; municipal service delivery; water and sanitation; long-term thinking; social ecological systems, panarchy

\section{Introduction: From municipal services to the 'long now'}

A notable feature of South Africa's water history since the transition to a multiracial democracy in 1994 has been the ever-increasing demand in the country's urban areas for proper water supply and sanitation service delivery. Since 2004 there has been a rising trend in civil protest, a trend that until 2011 became increasingly violent. Audits of the national department of water and sanitation (DWS) pointed to municipal under-performance in the process of rendering satisfactory services to consumers. This tendency was most notable in the rural areas of the country. Government became aware that there had been a specific bias when it came to funding. Most government funding for upgrades and the maintenance of infrastructure found its way to the country's large cities and metropolitan areas. ${ }^{2}$ The disenchantment with municipal service delivery was most pronounced in the field of water supply and sanitation. Research in a rural setting in North West Province in 2009 suggested that water-related issues were at the core of an estimated 60 per cent of the grievances residents had with municipal service delivery. ${ }^{3}$ However, water was seldom the strongest driver of protest action. Local and regional politics, and often personal feuds, also played a significant role in sparking conflict. Water-related issues were then added because water supply disruptions tend to create a volatile atmosphere of societal discontent - typically a sense of disenchantment with a local water supply authority. Water as a secondary driver of

1. Prof Johann Tempelhoff is a water historian working in the field of transdisciplinarity. He is leader of the Research Niche for the Cultural Dynamics of Water (CuDyWat) in the School of Basic Sciences, North-West University (Vaal Triangle, South Africa. Email: johann.tempelhoff@nwu.ac.za

2. African Ministers Council on Water (AMCOW), Water supply and sanitation in South Africa: Turning finance in services for 2015 and beyond (AMCOW Water and sanitation program, 2011), p. 15.

3. C Gouws, IM Moeketsi, S Motloung, JWN Tempelhoff, G van Greuning and L van Zyl, "SIBU and the crisis of water service delivery in Sannieshof, North West Province" in TD The Journal for Transdisciplinary Research in Southern Africa, 6(1) July 2010, pp. 25-56. 
conflict is well known. The 'water wars' theory in international politics ${ }^{4}$ suggests that water per se is seldom a primary cause of violence. Instead, water plays a secondary role. ${ }^{5}$ An exogenous and seemingly unimportant factor, situated on the periphery of the socialecological system of, for example, a local community, typically sparks off violent conflict, often leading to a state of collapse of certain available resources, requiring a dedicated and resilient adaptive response at the social level.

For the purposes of this discussion it is suggested that drivers of conflict are seated in deeper processes. For example, mobility and the tendency to live in communities has been a common feature of human society for thousands of years. In the case of water, changing conditions such as resource depletion, extended droughts, or floods, often lead to the decline and even collapse of a community's resilience in a large settlement.

The historical record shows that social-ecological circumstances tend to determine the demography of human settlement. In turn, these conditions are shaped by the dynamics of complex economic and political factors that come into play when processes of community formation begin against the backdrop of systemic growth of collective knowledge, eventually leading to the formation of complex cultural systems. ${ }^{6}$ A study of the history of human settlement shows that urbanisation, industry and human adaptation to ongoing processes of change may even terminate the continued existence of a local or regional society. Examples of this abound in the historical narratives of early urban societies in the Middle East, dating as far back as four millennia. ${ }^{7}$ Water supply, energy resources, along with road networks, and operational service institutions of social, economic and political governance, are of vital importance. ${ }^{8}$

Currently the population of sub-Saharan Africa (SSA) is increasing at a rapid rate. In 2013 it was estimated that the population of 1,1 billion would increase to 2,4 billion by $2050 .{ }^{9}$ Clearly, this implies that urbanisation in SSA is set to increase, along with that of Asia, at potentially the most rapid rate in the world. Indications are that these growth patterns will persist, at least for the next three decades. The growth is set to take place in urban environments. According to the United Nations' department of economic and social affairs,

4. AT Wolf, "Conflict and cooperation along international waterways" in Water Policy, 1, 1998, pp. 251265; AT Wolf, T. Aaron, "The transboundary freshwater dispute database project" in Water International 24(2), 1999, pp. 160-163; AT Wolf, “Water war' and water reality: conflict and cooperation along international waterways" in SC Lonergan (ed.), Environmental change, adaptation and security (Kluwer Academic Publishers, Dordrecht, 1999), pp. 251-265.

5. AT Wolf, A Kramer, A Carius and GD Dabelko, "Managing water conflict and cooperation" in State of the World 2005: redefining global security (Worldwatch Institute, Washington 2005), pp. 80-95 and 203-208.

6. D Christian, Maps of time: an introduction to big history (University of California Press, Berkeley, 2011), pp. 146-8, 253, 284, 290, 292-3.

7. D Northrop (ed.), A companion to world bistory (Wiley-Blackwell, Hoboken, 2012), p. 158; D Christian, Maps of time: an introduction to big history, pp. 269-275.

8. B Fagan, Elixir: a human history of water (Kindle edition, Bloomsbury, London, c.2011) Chapter 7.

9. Population Reference Bureau, (PRB), "World population data sheet" (2013) at http://goo.gl/yJOoN1 (Accessed 2014.07.31). 
only 36,7\% of sub-Saharan Africa's population was urbanised in $2011 / 2,{ }^{10}$ but by 2050 an estimated $56,5 \%$ could be resident in towns and cities. ${ }^{11}$ The chances are high that in southern Africa, particularly South Africa, with its urban population in 2005 of 59,3\% of the total population of the region, may push this urban tally up to $70 \%$ by $2050 .{ }^{12}$ Whilst there is consensus that urbanisation is a growing phenomenon in Africa, ${ }^{13}$ there are also critics who point out that the process should not only be equated with wealth and progress, but instead also with increasing poverty and the concomitant processes of de-urbanisation. ${ }^{14}$ What is evident is that human livelihoods in urban environments are bound to be subject to change. Although population growth could potentially lead to bustling metropolitan societies, it could also lead to decline. It depends on an intuitive ability of local communities to be responsive to the prevalent social ecological system and their ability to adapt in a resilient manner to on going processes of growth, collapse and recovery. There is a need to re-think the way communities accumulate and consume the available local resources. Apart from land, water is probably the most ubiquitous. There is a constant material demand for reliable water supplies and a societal need for the effective disposal of used water.

\section{The 'long now'}

In her contemplation of writing history in the era of globalisation, Lynne Hunt suggests that since the nineteenth century there has been a notable growth in the variety of communications systems. ${ }^{15}$ More particularly, the introduction of personalised computing and internet connectivity has compounded the process of knowledge production as a result of access to more sources of information. What is clear is that our understanding of the present and conceptions of an anticipated future are ostensibly focused on the short term. The abundance of contemporary data tends to obliterate potentially relevant historical information and unwittingly leads to states of social amnesia in which there is a deterioration of a fundamental historical consciousness. Rapid change and the apparent neglect of local and regional cultural dynamics is evident in matters of governance and socio-economic development in modernising states that are hard at work making headway in the era of globalisation.

In twenty-first century southern Africa, with its high growth potential, the focus of the region's governments is on extractive economic development. In the process, sustainability and the intrinsic relevance of history and cultural traditions are neglected in favour of the

10. Department of Economic and Social Affairs (DESA): Population division, World urbanization prospects: the 2011 revision (United Nations, New York, 2012), p. 121.

11. $\quad$ DESA, World urbanization prospects, p. 127.

12. DESA, World urbanization prospects, p. 127.

13. P Kok and N Collinson, Migration and urbanisation in South Africa, (Report 03_04-02, Statistics South Africa, Pretoria, 2006), p. 26.

14. D Potts, "Urban livelihoods and urbanization trends in Africa: winners and losers?" in Environment, politics and development working paper series, Paper 57, (King's College, London, 2013), pp. 1-30; D Potts, Whatever happened to Africa's rapid urbanization? (Counterpoints, Africa Research Institute, London, February 2012).

15. L Hunt, Writing history in the global era (WW Norton \& Company, New York, 2014), Chapter 2. 
quest for material gain. ${ }^{16}$ The safety and security of some resources, such as water, are easily compromised - often with negative consequences for local communities. How society needs to engage with these changes requires a memory of former times and cultural strategies of resilience, many of which have been lost in the era of modernisation. The question is: How do we deal with these complex issues and can we indeed learn from the past?

As fields of academic research broaden the focus on science and its impact on society, there is a growing sense of urgency to transcend boundaries of communities of practice so as to create knowledge and open up new frontiers of collaboration to provide guidance and sound advice for the sensible integration of Africa into global processes. Archaeologists, historians and anthropologists of Africa, working in comparative contexts, are now investigating the phenomenon of pre-colonial urban societies. They are focusing on the era before the onset of European colonisation, studying diverse localities on the subcontinent to reach a better understanding of local and coastal trade, and industrial activities related to mining and farming at the time. The objective is to determine how exogenous contact transformed social and economic livelihoods in pre-colonial times. ${ }^{17}$ For example, well-known heritage sites, such as Mapungubwe and Great Zimbabwe are now contemplated from the perspective of evolutionary processes of adaptation of pre-colonial African urban settlements and the influence of trading ties with the Indian Ocean economy. At the same time there are concerted efforts to link the long history of agriculture in East and Central East Africa to similar activities in Southern Africa over the past two millennia. ${ }^{18}$ The enigmatic hidden histories of terraced farming and settlement patterns, at localities such as Nyanga in Zimbabwe, and Bokoni in South Africa's Mpumalanga region, suggest complex community formations; intensive agricultural and pastoral activities; as well as indications of specialised water management strategies. There is a growing awareness that we need to investigate these aspects of the history of southern Africa from different perspectives to gain a better understanding of past and present forms of urbanisation. ${ }^{19}$ The reward could be a more responsible strategy for engaging with future development.

Historians are now re-interrogating the conventional South Africanised interpretation of Turner's frontier theory ${ }^{20}$ by suggesting, for example, that a colonially-shaped idealisation of the Cape's Eastern Frontier should be re-focused further north to the Limpopo-Shashe basin. ${ }^{21}$ Because we have the responsibility - in a post-colonial southern Africa - to reconsider the realities of governance, there is also a need to take note of pre-colonial local and regional governance entities. Moreover, in our understanding of early urban settlements

16. D Acemoglu and JA Robinson, Why nations fail: The origins of power, prosperity, and poverty (Profile Books, London, 2012), Chapter 13.

17. P Sinclair, "The archaeology of African urbanism" in P Mitchell and P Lane (eds) The Oxford handbook of African archaeology (Oxford University Press, Oxford, 2013), pp. 689-702.

18. OJJ Sinclair, G Nordquist, F Herschend and C Isendahl (eds), The urban mind: cultural and environmental dynamics (Uppsala University, Uppsala, 2010).

19. D Stump, "Intensification in context: archaeological approaches to pre-colonial field systems in Eastern and southern Africa" in African Studies, 69(2), August, 2010, pp. 255-278.

20. H Giliomee and R Elphick (eds), The shaping of South African society 1652-1840, Second edition (Maskew Miller Longman, Cape Town, 1989), pp. 3-108.

21. M Mulaudzi, MH Schoeman and S Chirikure, "Continuing conversations at the frontier" in South African Historical Journal, 62(2), 2010, pp. 219-228.

TD, 11(2), November 2015, Special edition, pp. 104-121. 
(not necessarily much different from their counterparts in other parts of the world) there is a need to understand historical consciousness cognitively, from the perspective of disciplines such as anthropology, archaeology and palaeontology. Much of the emergent research activity in southern Africa now focuses on the past half millennium from an archaeological perspective, with a strong accent on material remains. ${ }^{22}$

Although the broadening multi- and interdisciplinary field of investigation has a number of pitfalls, ${ }^{23}$ there are also opportunities. For example, there are good prospects for the historical appraisal of water and its place on a continent that relies heavily on precarious seasonal rainfall in the absence of sufficient natural surface storage facilities. ${ }^{24}$ Moreover, it is apparent that our fractured conceptualisation of the past, in which historians and anthropologists are considered the 'lumpers' and archaeologists the 'splitters', ${ }^{25}$ calls for a renewed investigation of the way in which we conceive society. By understanding the historical dynamics over long and extended periods, it might be possible for us to tease out the social-ecological systems that have shaped our understanding of the present. Taking a new perspective on the past may potentially stem the tide of disenchantment that is prevalent in a youthful and rapidly increasing population of ambitious and upwardly mobile Africans on the subcontinent.

For the purposes of this discussion I have singled out the concept of the 'long now', a term developed by the Long Now Foundation of which the inveterate futurist and innovator, Stewart Brand, has been a leading figure. The foundation's seminars on long-term thinking (SALT) have attracted interest in numerous fields of research. ${ }^{26}$ Underpinning the foundation's thinking is the objective of providing a counterpoint to today's accelerated thinking under circumstances of rapid technological innovation and change in an effort to promote a more common acceptance for longer-term thinking. ${ }^{27}$ Although Brand and members of the foundation focus firmly on the future, they do not hesitate to explore the past to enhance an understanding of the line of continuity between past, present and future.

To gain insight into the interplay of societal development over time, encapsulated in the "long now', the question that arises is: Will it be productive over an extended period of time to explore problems related to water on a subcontinent where the annual rainfall is well below

22. N Swanepoel, A Esterhuysen and P Bonner (eds), Five hundred years rediscovered: southern African precedents and prospects (University of Witwatersrand Press, Johannesburg 2009); P Lane, "Book review: Conversations between archaeologists and historians on South Africa" in The Journal of African History, 51(2) July 2010, pp. 251-3.

23. S Marks, "New paradigms in history and archaeology in South Africa" in African Studies, 70(1), 2011, pp. 123-143.

24. J Iliffe, Africa: the history of a continent, Second edition (Cambridge University Press, Cambridge, 2009), pp. 6-7.

25. S Dubow, Scientific racism in modern South Africa (Cambridge University Press, Cambridge, 1995), pp. 26 and 65; C Hamilton, BK Mbenga and R Ross, "The production of preindustrial South African history" in C Hamilton, BK Mbenga and R Ross (eds), The Cambridge History of South Africa: Volume 1, From early times to 1885 (Cambridge University Press, Cambridge 2012), pp. 1-65.

26. S Brand, K Kelly, A Rose and P Saffo, The SALT summaries: seminars about long-term thinking: October 02003-January 02003, Kindle edition (The Long Now Foundation, San Francisco, 2014).

27. M Chabon, "The Omega glory" in The Long Now Foundation at http://goo.gl/CyRkiA (Accessed 2014.09.08). 
the world average? Will it be possible for us to come to a better understanding of historical processes of climate change and how these influenced societies in terms of the availability of local water resources?

As a knowledge consuming society, focused on short-term and swift digital micro-byte spurts of information, all too often we seem to be content with the 'bigger picture' of trends that play out in the present - without exploring the past. If we are able to map a contingent connection and interaction between humans and the aquatic environment in southern Africa, in the distant past and in the present, we could potentially enhance our understanding of the future. Reframing our understanding time to accommodate the 'long now' will inevitably inform the manner in which we comprehend space.

\section{Outline}

For the purposes of this discussion the objective is to take a microhistorical snapshot of the town of Brandfort (founded in 1866), situated in the Masilonyana Local Municipality of South Africa's Free State Province, to form an understanding of local water-related problems residents have experienced in recent years. Apart from the contemporary water crisis, attention will be given aspects of the town's water history since the nineteenth century. By contemplating a larger regional history over an extended period of time, it should be possible to comprehend some of the present circumstances and anticipate aspects of the future of Brandfort.

\section{Brandfort's contemporary water problem}

Popular memory has it that Brandfort's critical problems with the town's water supply began in the early years of the new millennium and culminated in 2012 with protest marches and intermittent violence in the local black township. In many respects the historical trajectory of local residents' discontent with the state of affairs is similar to trends in other rural areas of South Africa where residents of small towns have been grappling with local water shortages. ${ }^{28}$ Underlying the public discontent there appears to be a sense of nostalgia for the days when local authorities were smaller and enjoyed greater local autonomy. The consolidation of small towns into larger municipal entities after 2000-2, are said to have been part of the problem. At the grassroots level residents are of the opinion that they would be far better off if their former local municipal status could be restored to stand-alone municipalities. They argue that this would at least give them greater autonomy over their own local matters. ${ }^{29}$ While governance experts are apt to discuss possible alternatives on an ongoing basis, it is people at grassroots level who have to bear the brunt of dysfunctional governance in rural local government. One consequence is a chronic lack of appropriate urban water supply services, in the rural parts of the country.

Brandfort is a good example. Residents of the town's former African township, Majwemasweu and the adjacent local informal settlements, often have to manage for days at a time without proper water supplies. The situation has worsened in recent years because of local population growth and intermittent breakdowns in a pipeline that connects the distant

28. JWN Tempelhoff, "Local service delivery problems and trends in South Africa's water governance (1994-2010)" Journal for Contemporary History, 36(3), December 2011, pp. 81-100.

29. N Steytler, "Urbanisation: single tier local government for urban areas" in Local Government Bulletin, 19(3), 2007, pp. 9-11.

TD, 11(2), November 2015, Special edition, pp. 104-121. 
water source to the town. Residents in the informal settlements have to cross a busy provincial road and walk a distance of five kilometres to fetch meagre water supplies for the household in $25 \ell$ containers. ${ }^{30}$ People who live in homes built on higher ground often have to cope without water for days on end when the level of the water in the local reservoir provides insufficient pressure to convey water through local pipelines to their homes. ${ }^{31}$ And at local schools, children are either sent home if water supplies are unavailable, or, as is the case at the town's high school with extensive boarding facilities, children have to resort to taking their bath soap and towels with them and taking a communal bath in the school's swimming pool. $^{32}$

The reasons for the water shortage in Brandfort are complex. The town relies heavily for its bulk water supply on the Erfenis Dam, situated in the Vet River catchment, south of Brandfort's neighbouring town of Theunissen. The dam, the third largest in South Africa at the time of its completion in 1960, forms part of the Sand-Vet irrigation scheme, a project started in 1947 with the Allemanskraal Dam, using water from the Sand River, for irrigating dryland areas in the central Free State. ${ }^{33}$ Since its completion the Erfenis Dam has been responsible for supplying water to Brandfort. The water is pumped along a pipeline of about $35 \mathrm{~km}$ to Brandfort's reservoirs.

Since the 1990s, in response to the government's reconstruction and development policy (RDP), there has been a significant inflow of new residents to Brandfort. The promise of free housing saw many South Africans, who were formerly employed on farms, moving into the country's small towns in anticipation of a house of their own and a reasonably comfortable urban lifestyle. At the same time white farmers, in the face of the land redistribution legislation that came into effect after 1994, have subtly pushed labourers off their farms in an effort to prevent possible land claims and restitution issues on their property. In the Free State, primarily a dryland farming area producing a third of the country's wheat and maize, ${ }^{34}$ this population shift has had a marked effect on urbanisation trends, specifically in many of the province's smaller towns. ${ }^{35}$

For obvious reasons the water supply to a town like Brandfort proved insufficient after 1994. With the advent of multiracial democracy, government policy was to provide all South Africans in urban areas with potable water and proper sanitation. The Bill of Rights, chapter

30. N Seleka, "Water worries put a daily strain on Brandfort residents" in Sowetan Live, 2013.02.20 athttp://goo.g1/8vNKcV (Accessed 2014.03.20); M Ginster, JWN Tempelhoff, L van der Merwe, S Berner, S Motloung and U Rabali, Running on empty: investigating the 2013 Brandfort water supply crisis (Research Niche for the Cultural Dynamics of Water (CuDyWat), North-West University (Vaal), Report 1/2013. Finalised 2014.06.28), pp. 26-27.

31. Ibid., pp. pp. 34-37.

32. Ibid., pp. 38-41; Anon., "Swimming? No, we are bathing” in You Magazine, 2013.03.28, pp. 124-125.

33. AR Turton, R Meissner, PM Mampane and O Seremo, A hydropolitical history of South Africa's international river basins (WRC Report 1220/1/04, Water Research Commission, Pretoria, 2004), pp. 174-175.

34. M Hensley, P le Roux, C du Preez, C van Huyssteen, E Kotzé and L van Rensburg, "Soils: the Free State's agricultural base” in South African Geographical Journal, 88(1), 2006, pp. 111-21.

35. L Marais and A Pelser, "Voting with their feet: population trends and policy-making in the Free State" in South African Geographical Journal, 88(1), 2006, pp. 22-31. 
2, section 27, in the 1996 Constitution of South Africa, Act 108 of 1996, the National Water Act, 36 of 1998, as well as the government's commitment to the United Nations' Millennium Development Goals (MDGs) have been the prime markers in the process of promoting equity in access to proper water and sanitation for all people resident in the country. ${ }^{36}$ The problem in Brandfort, as has been the case in many rural South African towns, is that there was not enough water to ensure a consistent supply for all. ${ }^{37}$ The ageing infrastructure was unable to provide the increased demand for potable water supplies - an endemic problem in many of South Africa's urban areas for some time. ${ }^{38}$ Furthermore, as of 2008, because of the increasing countrywide electricity load shedding, water pumping systems, as well as water purification and wastewater treatment plants intermittently came to a halt. In the case of Brandfort, the electrically operated pumps at the Erfenis Dam were out of service for extended periods of time. This in turn meant that when the electricity was restored, the supply of water was prone to burst the pipelines because of inconsistent pressure levels. ${ }^{39}$

In 2012-3 there were several protest marches. The Democratic Alliance (DA), the official opposition at the municipal and provincial level in the Free State, maintained a high profile in residents' protest actions against inferior water and sanitation service delivery. ${ }^{40}$ This political party has for several years taken the authorities to task for the dire condition of the province's urban water and sanitation infrastructure. ${ }^{41}$ The DA relied heavily on the Human Rights Commission to report on lapses in the basic human right of access to proper drinking water. ${ }^{42}$ In the case of Brandfort, a local resident who served as a ward representative on the municipal council, conducted a comprehensive investigation and subsequently wrote a report on Brandfort's water and sanitation problems. A copy of the report was later submitted to the provincial Human Rights Commission in Bloemfontein. ${ }^{43}$ Until 2013 all attempts at making

36. H Thompson, Water law: A practical approach to resource management and the provision of services (Second impression, Juta, Cape Town, 2006) pp. 197-8; Republic of South Africa (RSA), Millennium Development Goal: Country report 2013, at http://goo.gl/8cLwtp (accessed 2015.08.16) pp. 18-19, 22, 93, 99-101.

37. M Ginster, JWN Tempelhoff, L van der Merwe, S Berner, S Motloung and U Rabali, Running on empty: investigating the 2013 Brandfort water supply crisis, p. 51.

38. A Vermeulen and M Lipholo, "Preserving water resources" in IMIESA, 35(7), July 2010, p. 41.

39. M Ginster, JWN Tempelhoff, L van der Merwe, S Berner, S Motloung and U Rabali, Running on empty: investigating the 2013 Brandfort water supply crisis, pp. 15-16, 65 .

40. Ibid., pp. 28-29.

41. R Jankielsohn, "Defining hydropolitics: the politics of water in South Africa" in Journal for Contemporary History, 27(1), 2012, pp. 123-141.

42. JWN Tempelhoff, AS van Zyl, EJ Nealer, M Ginster, S Berner, IM Moeketsi, M Morotolo, A Tsotetsi and P Radebe, Environmental health and the hydrosophere in Moqhaka Local Municipality, Free State South Africa (CuDyWat Report 2/2011, North-West University (Vaal), Vanderbijlpark, 2011); M Ginster, JWN Tempelhoff, L van der Merwe, S Berner, S Motloung and U Rabali, Running on empty: investigating the 2013 Brandfort water supply crisis, pp. 28-29; JWN Tempelhoff "From Makhaza to Rammulotsi: Reflections on South Africa's "toilet election" of 2011" Historia57(1), May 2012, pp. 82-108.

43. F Posthumus, Brandfort Water Supply Services. Technical Investigation Report (Report 08/2011). A report compiled for the Minister of Water and Environmental Affairs Hon. E Molewa and copy for Public Protector Sun Griessel. 
local, provincial and national authorities aware of Brandfort's water plight appeared to be futile.

\section{Brandfort's water since the nineteenth century}

Brandfort was founded in October 1866, a year after an army of about 2500 Basotho warriors of Lesotho marched into what was then the Afrikaner republic of the Orange Free State (1854-1902). At the instruction of their leaders, Masupha and Moperi, the Basotho reportedly brutally massacred the white settlers in the region. ${ }^{44}$ The subsequent founding of Brandfort suggests that the settlement formed a frontier outpost of the Orange Free State. Similar towns, Frankfort $(1869)^{45}$ and Vredefort (1876), were founded at more or less the same time. ${ }^{46}$ As their names suggest, these settlements were strategic local fortification points aimed at safeguarding frontier farming communities.

Water always plays an important role in the founding and development of urban settlements. In the case of Brandfort, the Keeromspruit was a decisive factor in determining where the new frontier town would be situated. In fact the local spruit provided water for all types of animals, and if we go by what palaeontologists tell us, also early humankind. ${ }^{47}$ Legend has it that the Voortrekkers, who first came across the site during one of their reconnaissance excursions from the Cape into the trans-Orange region, named the Keeromspruit and the nearby Keeromberg. It was here that they decided to turn around (omkeer) and go back home to their families. ${ }^{48}$ The Keeromspruit is fed from a fountain system in the surrounding low mountain range. The water gravitates downstream and passes into the stream at the lower end of the town of Brandfort.

Van Zyl has queried the claim that water was a major factor in emergent human settlement patterns in the Orange Free State. ${ }^{49} \mathrm{His}$ focus on central place theory for comprehending settlements patterns in the region (1840-1910) tends to downplay the importance of water. However, he does acknowledge that availability of water might well have been one of the causative factors in the founding and development of towns in the area. As an example, he mentioned that the rapid growth of Kroonstad, which was quicker than that of Winburg, was perhaps because of the copious supplies of water available at Kroonstad's Vals River. ${ }^{50}$

44. GM Theal, History of South Africa since 1795 (Cambridge University Press reprint, New York, 2010), p. 169.

45. PE Raper, New dictionary of South African place names (Jonathan Ball, Johannesburg and Cape Town, 2004) p. 105.

46. Ibid., p. 396.

47. ER Collins, "Stone implements from South African gravels" in The Journal of the Anthropological Institute of Great Britain and Ireland, 45, January/June 1915, p. 82.

48. Brandfort Library, History Clippings File (hereafter BLHCF), Herinneringe van J vd V Dreyer oor Brandfort in die vroeë jare, (April 1978), p. 2.

49. JA Van Zyl, "Blanke vestigingspatrone in die Oranje-Vrystaat: vroeë blanke vestiging en stedelike groei tot 1910” in Acta Geographica, 1, 1967, p. 166.

50. Ibid., p. 173; For more on the Vaal River and its contemporary history, see JWN Tempelhoff, AS van Zyl, EJ Nealer, M Ginster, S Berner, IM Moeketsi, M Morotolo, A Tsotetsi, P Radebe, Environmental health and the hydrosphere in Moghaka Local Municipality, Free State, South Africa 
In the case of Brandfort it is certain that the Keeromspruit and its groundwater supply played an important role. Between 1866 and 1904 the white population of Brandfort increased on average by about 24 people per annum. ${ }^{51} \mathrm{Up}$ to the end of the nineteenth century, a local population of 200 residents would have made up a large country town. What is evident of Brandfort is that local population increases tended to coincide with periods of social and political upheaval. It grew most rapidly in the period 1890 to 1904 - at the rate of 394 per cent. $^{52}$ The South African War (1899-1902) significantly influenced this growth. Brandfort has a special place in the history of the war. ${ }^{53}$ There were two civilian camps on the outskirts of the town - Dwyersdorp for whites and Nooitgedacht for Africans. Little information has survived on the black concentration camp, but we do know that in both camps water-related diseases such as typhoid and dysentery flourished and that measles was also prevalent, especially among children. ${ }^{54}$ Mortality rates were high. According to Reynolds, 1646 civilians died at Brandfort between January 1901 and March 1903. ${ }^{55}$ Van Heyningen points out that the local camps also experienced the highest mortality rates of all camps in South Africa in a single year, with 1166 per 1000 for the period October 1900-1, which in effect means that the camp's residents could have been completely exterminated by disease had the local population remained static. ${ }^{56}$

There was widespread poverty amongst the whites after the war. Consequently, many families were slow to return to farms that had been destroyed. Some chose to move to the urban areas of the Witwatersrand where the men hoped to find employment on the mines or in industries. Africans, who had been in the employment of white farmers before the war, were also in a precarious position. ${ }^{57}$ Many civilians who had become refugees during the war stayed on in rural towns. Therefore, it did not come as a surprise that Brandfort, the former camp town of the war, became a political hotspot of civil protest in 1903 when local residents held the first meetings to demand compensation from the British authorities for the losses they had suffered during the war. In 1904, congresses in Brandfort and the capital city of

(Research Niche for the Cultural Dynamics of Water, NWU Report 2/2011. Fezile Dabi Project (FDP).

51. JA van $Z y l$, "Blanke vestigingspatrone in die Oranje-Vrystaat: vroeë blanke vestiging en stedelike groei tot 1910" in Acta Geographica, 1, 1967, p. 187.

52. Ibid., p. 186.

53. See Anon., De Camp Courant at http://goo.gl/FgoM9x, a website dedicated to highlight events in British concentration camps during the Anglo Boer War (Accessed 2014.02.15); E Van Heyningen, "The Concentration Camps of the South African (Anglo-Boer) War, 1900-1902", History Compass, 7(1), January 2009, pp. 22-43.

54. Anon., De Camp Courant athttp://goo.g1/FgoM9x, a website dedicated to highlight events in British concentration camps during the Anglo Boer War (Accessed 2014.02.15).

55. CMM Reynolds, Die ontwikkeling en analise van ' $n$ elektroniese genealogiese databasis oor burgerlike sterftes tydens die Anglo-Boereoorlog (1899-1902), (MA, NWU, Vaaldriehoek, 2007), p. 54.

56. E van Heyningen, "A tool for modernization? The Boer concentration camps of the South African War, 1900-1902" in South African Journal of Science, 106(5/6), pp. 1-10.

57. PAH Lanbuschagne and CJ van Vuuren, "The destiny of the human family and Johannes Seseane in the Winburg district during the Anglo Boer War (1899-1902)" in South African Jourbnal for Cultural History, 24(1), June 2010, pp. 36-57. 
Bloemfontein culminated in the formation of the first post-war political party of the Free State, the Orangia Unie, two years later. ${ }^{58}$

There are frequent references to water in the history of Brandfort. In the top part of town there was a relatively weak fountain that provided water for the canal that ran alongside Water Street. The town's other fountain was near the station. The water furrow on the main road joined the water from the top fountain at Water Street and was directed down the street in the direction of the Keeromspruit. ${ }^{59}$ The symmetrical layout of the town favoured gravity for distributing the available water supplies in town. Residents eagerly linked up to the water supply system and everyone had a turn to lead water into their gardens from the furrow. The first water-users were those who owned erven in Marais Street. These plots of land were by far the largest in town and were intended for extensive gardening. However, even in the early 1900s the water supply was apparently insufficient and later it completely dried up. ${ }^{60}$

The first modern interventions in the groundwater supply of Brandfort appear to have started early in the twentieth century when a certain Gustave D'Assonville of the Cape Colony, moved to the town. He began drilling boreholes, powered by wind pumps, for resident farmers in the district. ${ }^{61}$ The townspeople were industrious. In addition to a mill used by the local blacksmith, there was a steam mill used for grinding maize and wheat, ${ }^{62}$ and a soft drink factory run by Joe Hoffman. The factory produced lemonade in glass bottles with marble stoppers and at the time the water was said to have been sparkling clean. ${ }^{63}$ According to an elderly resident of Brandfort, after heavy rain the local children would catch small silver fish in the town's water furrows. ${ }^{64}$ Brandfort's first power station came into operation in 1923. Its turbines required steaming water from a boiler to generate electricity. The new plant replaced a gas lighting system introduced shortly after the South African War. ${ }^{65}$

A major intervention in the town's water supplies dates back to the 1960s with the introduction of pumped water supplies from the Erfenis Dam, forming part of the Sand-Vet irrigation scheme. Brandfort's new water system, constructed at a cost of R240 000, was officially taken into use on 2 December $1963 .{ }^{66}$ The Erfenis Dam's gross capacity at the time of its completion stood at 237 million cubic metres and at any one time it could release as much as $3170 \mathrm{~m}^{3} / \mathrm{s}$ over the spillway. ${ }^{67}$ Brandfort's heydays were at the beginning of the 1960s, after one of its local residents, CR Swart (1894-1982), became the first state president

58. DA van der Bank, "Die Orangia Unie as volksvereniging en politieke party, 1906-1912” in Navorsinge van die Nasionale Museum, 10(9), 1994, pp. 355-361.

59. BLHCF, Herinneringe van JvdV Dreyer oor Brandfort in die vroeë jare, (April 1978), p. 5.

60. Ibid., p. 5.

61. Ibid., p. 2.

62. Ibid., p. 3.

63. Ibid., p. 3.

64. Ibid., p. 5.

65. Ibid., p. 8.

66. Spesiale verteenwoordiger. "Ons het net een land en hom moet ons bou" in Die Volksblad, 1963.12.03.

67. SANCOLD, Typical large dams in South Africa (South African National Committee on Large Dams, September 1978,) p. 36. 
of the Republic of South Africa on 31 May $1961 .^{68}$ The local history album in the town's library reflects the long-lasting bond of friendship between the former state president and local townspeople. ${ }^{69}$ Towards the end of the 1960s Brandfort's star began to wane.

The significance of Brandfort's water supply for communication purposes underwent marked changes at the time. For many years the town was situated on one of the main communication routes in the Free State and benefited economically from the trade and commerce that flourished with travellers passing through town. In the nineteenth century the town had been a major stopover point for east-west travellers between Natal and Kimberley's diamond fields. Until the second half of the twentieth century Brandfort was situated on the main north-south railway line between Cape Town and the Johannesburg. However, gradually the importance of rail transportation diminished. First diesel and then electric locomotives replaced steam trains and Brandfort's strategic importance declined as a stopover point for re-filling coal-fired locomotives' water tanks. Initially, the gains for the town were more significant than the losses. Eskom serviced the local railway line and it meant that Brandfort now secured a stable Eskom energy supply as of 1976, replacing a service previously provided by Bloemfontein. ${ }^{70}$ Then too, for a while, road transport increased and the traffic between Cape Town and Johannesburg called in on the main road passing through downtown Brandfort. Brandfort became a bustling town on one of the busiest main thoroughfares in South Africa, popularly known as the Great North Road. However, this upsurge was again destined to wane. In the 1970s the main roads of South Africa were overhauled and the new N1 highway by-passed Brandfort. ${ }^{71}$ Before long the settlement acquired the status of a less-than-prosperous town. What did remain was its architectural heritage making it one of the Free State's 'stately small towns' with picturesque Victorian and Edwardian architecture - a mere stone's throw away from the thriving provincial capital of Bloemfontein (Mangaung). Over the years Brandfort remained the urban hub of a wealthy farming district and the local schools had a proud reputation for providing outstanding education. On Fridays the district's farming community used the town as a shopping destination when they collected their children from boarding school to spend the weekend at home.

Brandfort's reputation as a sleepy hollow in the Free State came to an abrupt end in the aftermath of the 1976 Soweto student protests, when in May 1977 Ms Winnie Madikizela Mandela, who had earlier been restricted to her home in Orlando West, Soweto, was relocated to Brandfort's Majwemasweu township. The government's security police raided her Soweto home early one morning and she and members of her family were taken from a comfortable three-bedroomed house to one in the Free State with no water, sanitation or electricity. In the eight years (1977-1985) she spent in the town, the wife of Nelson Mandela (at the time still incarcerated on Robben Island) became an influential figure. ${ }^{72}$ At the time

68. Anon., "Republiekfees op Brandfort" in Die Volksblad, 1961.05.11; Spesiale verteenwoordiger, "Mnr Swart gehuldig: Afrikanerhart is tot volk se beskikking" in Die Volksblad, 1961.05.11.

69. BLHCF, D Meyers, “'Eie mense' vereer Oom Blackie” (Anonymous newspaper clipping) dated 1981.05.29.

70. Anon., "Brandfort baat baie" in Volksblad, 1976.04.12.

71. Anon., "Dorp en land groei hand aan hand" in Die Volksblad, 1972.09.01.

72. W Watson, Brick by brick: an informal guide to the history of South Africa, (New Africa Books, Claremont, 2007), p. 93; C Twala, "Winnie Mandela banishment house in Brandfort (Majwemasweu) 
Brandfort became a town of infamy in the discourse of the struggle against apartheid. Contemporary news articles on her time in Brandfort, speak of the stark contrasts and bitter exchanges of members of civil society in a community grappling with issues of race in apartheid South Africa. ${ }^{73}$ Within the next three decades problems related to municipal water supply created circumstances in which the town's white and African population found common cause and sought solutions - sometimes by means of collectively protesting and collaborating - to secure a reasonable water supply to lead a dignified domestic life in Brandfort. $^{74}$

\section{Exploring deeper trajectories of time and space in the 'long now'}

Since time immemorial, water has been a strategic natural resource in the Brandfort area. This is a region that is currently classified as semi-arid and lies on the edge of the Karoo and Kalahari. Over the centuries, water has been a crucial natural resource essential for fauna and flora on the plains and the low mountainous landscape surrounding Brandfort. The town is situated in a transitional zone, i.e. it is representative of the transition from a Highveld grassland region to a Karoo steppe-type landscape with a lower rainfall. A notable feature of the landscape to the immediate northwest of Brandfort is a number of saltpans extending over a significant area up to the edge of the Kalahari. These pans tend to lie in the more arid parts of the region that have a $500 \mathrm{~mm}$ mean annual isohyet and a $1000 \mathrm{~mm}$ free surface evaporation loss line. They are found in a belt running southwards from Kroonstad, through Wesselsbron, Boshoff and Dealesville. ${ }^{75}$ The pans in the western parts of the Free State tend to be situated in Ecca series rocks. However, Brandfort, as is also the case with Bloemfontein and Welkom, is situated in the neighbouring Beaufort series, ${ }^{76}$ where the dispersion of endemic flora is different.

At Florisbad, a hot spring resort near the settlement of Soutpan not far from Brandfort, the palaeontologist TF Dreyer discovered the Florisbad skull in 1932. ${ }^{77}$ Archaeological research has established that the hot spring at Florisbad, the product of tectonic activity, ${ }^{78}$ started

- its historical significance: 1977-1902” in South African Journal of Cultural History, 22(2), 2008, pp. 6685 .

73. BLHCF, L Gomes, "Groot name en oues" in Volksblad, Junie 1977 (No date disclosed in clipping); D Levin, "Fresh-air Brandfort won't set the tourists on fire” in Sunday Times, 1977.06.12.

74. M Ginster, JWN Tempelhoff, L van der Merwe, S Berner, S Motloung and U Rabali, Running on empty: investigating the 2013 Brandfort water supply crisis (Research Niche for the Cultural Dynamics of Water (CuDyWat), North-West University (Vaal), Report 1/2013. Finalised 2014.06.28).

75. AS Goudie, and GL Wells, "The nature, distribution and formation of pans in arid zones" in Earth Science Reviews, 38(1), March 1995, p. 6.

76. Ibid., p. 29.

77. P Bonner, A Esterhuysen and T Jenkins, "Voice of politics, voice of science: politics and science after 1945" in P Bonner, A Esterhuysen, and T Jenkins, (eds.) A search for origins: science, bistory and South Africa's 'Cradle of Humankind' (Wits University Press, Johannesburg, 2007), p. 276; K Kuman, M Inbar $\mathrm{M}$ and RJ Clark, "Palaeoenvironments and cultural sequence of the Florisbad Middle Stone Age hominid site, South Africa" in Journal of Archaeological Science, 26(12), December 1999, p. 1409.

78. GCP King, and GN Bailey, "Dynamic landscapes and human evolution" in Geological Society of America, Special paper, 471, 2010, pp. 9-10. 
gushing water from about 279000 until $\pm 47000 \mathrm{yBP} .{ }^{79} \mathrm{King}$ and Bailey argue that sites of tectonic activity in South Africa created favourable conditions for early humankind to use local resources. ${ }^{80}$ Some 20000 years after the formation of the spring, a direct predecessor of modern Homo sapiens, described as Homo helmei, ${ }^{81}$ was present at Florisbad. ${ }^{82}$ (S)he was not healthy, showing signs of anaemia and tooth decay - probably the result of living in changing climatic conditions. ${ }^{83}$ At the time, the Florisbad landscape was frequently windswept and most of the vegetation growing at the brackish spring comprised salty marsh plants. ${ }^{84}$ Heated and/or saline water supplies periodically attracted wild animals, especially in the drier times. In wet seasons there were pools and local springs were active, but in drier periods the area would have been swampy. There were numerous changes in local climatic conditions and at times the site was less accessible to hominins. When the region was swampy there was little evidence of pools. ${ }^{85}$ Then too, the landscape could change to an extended shallow lake where large numbers of wildlife gathered for extended periods of time.

Middle Stone Age people visited the site and there are abundant indications of tool production. Stone tools were even re-used by successive generations. So profuse are the traces of these people that archaeologists have labelled the site as representative of the 'Florisbad industry' and explain that Middle Stone Age people visited the site until as recently as 19500 BP. ${ }^{86}$ Some time in the early Late Stone Age (after 25000 yBP) glacial conditions temporarily prevented humans from frequenting the area. ${ }^{87}$ However, between 12000 and $6000 \mathrm{yBP}$, there are indications that Late Stone Age people were present. ${ }^{88}$ Local conditions were ideal for hunting and there is evidence that hunters used bone and stone tools for butchering the flesh and extracting marrow from the bones of their prey. ${ }^{89}$ With the area's wide range of natural vegetation, foraging probably supplemented their basic diet. ${ }^{90}$ Late

79. K Kuman, M Inbar and RJ Clark, "Palaeoenvironments and cultural sequence of the Florisbad Middle Stone Age hominid site, South Africa" in Journal of Archaeological Science, 26(12), December 1999, p. 1419 .

80 . GCP King, and GN Bailey, “Dynamic landscapes and human evolution”, pp. 9-10.

81. K Kuman, M Inbar and RJ Clark, "Palaeoenvironments and cultural sequence of the Florisbad Middle Stone Age hominid site, South Africa”, p. 1411.

82. GN Bailey, SC Reynolds, and GCP King, "Landscapes of human evolution: models and methods of tectonic geomorphology and the reconstruction of homonin landscapes" in Journal of Human Evolution, 60(3), March 2011, p. 269.

83. D Curnoe and JS Brink, "Evidence of pathological conditions in the Florisbad cranium" in Journal of Human Evolution, 59(5), November 2010, pp. 504-513.

84. JD Clarke, "Human ecology during the Pleistocene and later times in Africa south of the Sahara", in Current Anthropology, 1(4), July 1960, p. 318.

85. K Kuman, M Inbar and RJ Clark, "Palaeoenvironments and cultural sequence of the Florisbad Middle Stone Age hominid site, South Africa” p. 1414.

86. Ibid., p. 1422.

87. Ibid., p. 1422.

88. Ibid., p. 1422.

89. Ibid., p. 1420.

90 . Ibid., p. 1421.

TD, 11(2), November 2015, Special edition, pp. 104-121. 
Stone Age people tended to live at the edges of the springs but seldom remained in the same place for very long. The evidence points to their living for more lengthy periods in neighbouring coarse landscape areas where there were shelters such as caves, and on the nearby savannah plains. Nineteenth-century observers tell us that wildlife was endemic in the region of the pans, especially those in the western Free State and Northern Cape, and that the wildlife trampled the areas around the water when they came to drink, enlarging the surface area of the pans. According to one contemporary observer as many as 8000 blesbok were seen on one occasion at a pan in the region..$^{91}$ In the context of a larger regional landscape, Florisbad was a locality frequented by humans who probably resided at more favourable locations elsewhere. These would have been areas with undulating plains, low mountains and sufficient water supplies - such as those of Brandfort.

\section{Discussion and conclusion}

Since the 1990s, Gunderson and Holling's development of panarchy theory ${ }^{92}$ has potentially opened the way for historians to gain access to discourses related to resilience and the environment. ${ }^{93}$ Panarchy downplays rigid cyclical theorisation, which is why many hermeneutic historians remain wary of its use. By accentuating infinity on scales that vary in magnitude and spatiotemporal contexts, panarchy accommodates the compartmentalisation of complex systems. ${ }^{94}$ The latter can then be associated with processes of change, which may occur in the thick of, or on the periphery of ongoing trends within the system. Small-scale panarchical cycles tend to result in revolt, whereas a large-scale cycle notably accommodates the accumulation of codes of memory that support recovery and the productive use of resources. ${ }^{95}$ In essence, panarchy aims to provide insight into the way social ecological systems adapt to change. Whilst there is acceptance that there are phases of collapse, these are alternatively interpreted as processes of 'creative destruction' that may lead to recovery and opportunities under circumstances where resource conservation and consumption remain in a state of non-equilibrium. Maintaining sustainability in complex cycles of panarchy requires constant adaptation of the social ecological system. Depending on the dynamics of the social ecological system there are, by implication, constant prospects for states of regime change. ${ }^{96}$

Contemplating today's Brandfort from the perspective of panarchy, suggests that local natural water supplies, be they salty or fresh, have historically had a marked impact on the regional human footprint. The landscape would seldom have been densely populated because there

91. AS Goudie and GL Wells, "The nature, distribution and formation of pans in arid zones" in Earth Science Reviews, 38(1), March 1995, p. 61.

92. LH Gunderson and CS Holling, Panarchy: understanding transformations in human and natural systems (Island Press, Washington DC, 2002).

93. See for example an insightful reflection see M Gotts, "Resilience, Panarchy and World Systems analysis" in Ecology and Society, 12(1), 2007, pp. 1-14.

94. GR Allen, DG Angerler, AS Garmestani, LH Gunderson and CS Holling, "Panarchy: Theory and application" in Ecosystems, 17, 2014, p. 580.

95. CS Holling, "From complex regions to complex worlds" in Minnesota Journal of Law, Science and Technology, 7(1), 2005-6, p. 1.

96. B Weeks, MA Rodriguez, JH Blakeslee, "Panarchy: complexity and regime change in human societies" in Proceedings: Santa Fe Institute, 2004. 
was not always an abundance of natural resources conducive to long phases of human residence. Furthermore, the social ecology ${ }^{97}$ of the region suggests that human groups passing through the area formed part of flows of human migration. They left their imprint as lines on the landscape with points and counterpoints, as well as fluid spaces that featured prominently in the process of human mobility. Like the web of a spider, there were diffuse and immediate responses throughout the system when lines randomly interlocked and criss-crossed in space. $^{98}$ Most common were the water points and human movements that were frequently interwoven. When human migration over time is contemplated as interactive webs in space, it is possible to identify layers of panarchy cycles. Although they have never been identical, some elements of these cycles, such as the need for water supplies, have remained as a common feature.

There are traces of Middle Stone Age humans on the land in central South Africa, suggesting that up to 19000 years ago industrious communities formed part of the landscape in the proximity of water-rich ecosystems in central South Africa. Late Stone Age people prepared the way for what would later become the San and their descendants, the Khoekhoe. The latter were small groups and communities who became familiar with the technologies of pastoral lifestyles introduced by Iron Age communities in southern Africa in about 2000yBP.

By the eighteenth century, population pressure and changing environmental conditions, to the east of the Ukahlamba-Drakensberg escarpment prepared the way for a substantial Nguni presence in central South Africa. These people resided alongside Sotho and Tswana communities who had been in in the region for several centuries. Towards the end of the eighteenth century, adventurers, explorers and hunting pastoral farmers of European descent began to frequent the trans-Orange River region. Along with the first missionaries, they paved the way for the emigration from the Cape Colony (1835-1852) of large groups of Dutch farmers. In fact, ever since the 1830s the Brandfort region has become a region notable for criss-crossing routes for people travelling between the coast and the interior.

What became the settlement of Brandfort with its water resource, the Keeromspruit, served for centuries as a watering point for various meandering migratory groups. The area held enchantment; it offered shelter and essential resources. The land was capable of carrying a finite sedentary human population.

The first real thrust towards a substantive urban settlement followed in 1866 as part of a strategic measure by a republican-styled polity to maintain a presence on a frontier region where humans engaged in cultural exchanges. The Keeromspruit became part of a transitional landscape, still constantly subject to conditions of periodic droughts and floods, but also war and peace. The remains of stone weirs and storage tanks in the upper reaches of the Keeromspruit date back to the early days of the settlement. As the local community became more sophisticated they began to use innovative strategies to store water for communal use.

97. The contemporary understanding of social ecology essentially implies the understanding of bioecological and macro-economic concerns, with a greater focus on the social, psychological, institutional, and cultural contexts of people-environment relationships. These were previously overlooked. See D Stokols, PR Lejano and J Hipp, "Enhancing the resilience of human-environment systems: a social ecological perspective" in Ecology and Society, 18(1), 2013, at http://dx.doi.org/10.5751/ES-05301-180107 (Accessed 2013.10.25).

98. T Ingold, Being alive: essays on movement, knowledge and description (Routledge, Abingdon, 2011), Chapters 5-7. 
Later the technology of steam-powered railways required more water supplies. The use of water for mechanical power generation implied management strategies that could have caused cycles of collapse and gradual recovery of the water supply. The finite local water supplies required careful management strategies.

The large civilian population during the abnormal years of war (1899-1902) jeopardised local environmental health. Deadly waterborne diseases such as typhoid fever and diarrhoea, posed a threat. As the incarcerated civilian population increased, the Keeromspruit was unable to contend with the demand for potable water; there was not sufficient water to ensure a healthy local aquatic ecosystem. Following the war, homeless farming families congregated in the town before dispersing either to their farms and homesteads (most of which had been destroyed) or moving on to the larger urban settlements.

When the local water supplies were suitable for human consumption, there was social development and economic growth. Over-consumption and the careless use of local water resources led to states of collapse and the need for interventions - more than often primarily engineering technologies, aimed at securing more water supplies. Supplies of water were piped from distant man-made water storage facilities. In years of progress the modern system of water supply sustained development and growth. However, as human communications technologies and migration routes changed, the economic sustainability of the local social ecology was compromised.

Consequently, under circumstances of political regime change, it became difficult to maintain technologies for pumping water in a pipeline over an extended distance. A phase of intermittent change was partly due to serious lapses in the management of available water resources. Importantly, excessive population pressure also compromised the local ecology. By 2013, the environmental health of the Keeromspruit, which had meanwhile primarily become a conduit for wastewater, was overpopulated with exotic vegetation feeding on valuable groundwater. Largely because of neglect, the local aquifer was unable to provide the needs of residents. Downstream of the railway bridge, the wastewater treatment plant had become dysfunctional. The human neglect of the local natural water supply was symptomatic of a lack of concern for environmental health - an important strategic link between humankind and the natural environment in an urban environment.

In 2012, when the local water crisis culminated in the community's protest action, Brandfort had insufficient drivers of development and the panarchy cycle moved into a phase of collapse. Local water resources were no longer readily accessible for residents. Significantly, neither was there a strong demand for goods and services and entrepreneurial skills that could otherwise have boosted industry, trade and commerce. The momentum of a surge for making headway under circumstances of creative destruction, was clearly absent. Yet, the process of urbanisation persisted with the on going population growth in the local informal settlement. The expectations of farm workers who were moving into the town were not met. Not having access to domestic water supplies contributed to the disenchantment among local residents. Moreover, the large urban conurbation of Bloemfontein, about $50 \mathrm{~km}$ from Brandfort, tended to attract Brandfort residents who had the skills to promote rapid urban development; they became commuters between the city and the town. Meanwhile, population pressure put the inconsistent local water supply to the test. The community did not have the necessary resources at their disposal to address the problem at grassroots level. This meant that residents became increasingly dissatisfied with the local authority responsible for infrastructure governance. 
The 'long now' - if we slice the past up into infinite cycles of change in time and space - is able to shed light on a better understanding of how we form an intrinsic part of an ecological system that is constantly and spontaneously adapting to changing circumstances. Ever since the beginning of the twentieth century there have been interventions in Brandfort by means of engineering the environment. Was this also the case in former times? How then should we contemplate the disciplines of palaeontology and archaeology from an ontological perspective to gain insight into the deep history of the region? One method is to pursue Diltheyan hermeneutics. This requires an understanding of concepts, judgements and related purethought formations; an understanding of life manifestations; and the need to work towards the expression of lived experience..$^{99}$ Forming an impression of local residents in the Middle Stone Age makes it possible reach an understanding of a time when water was key to the human presence on the land. Only much later did humans resort to artificial strategies of manipulating water supplies. To date, the anthropogenic inclination to engineer the local aquatic environment has not always been successful. Knowledge of the deep history of humankind and its interaction with nature suggests that over the ages, communities have introduced innovative changes and have managed to cultivate skills to flourish under adverse conditions. This has been the trend ever since the formation of communities with the onset of the Holocene epoch more than 11000 years ago. ${ }^{100}$

At a time when there are concerns about water security under circumstances of rapid urbanisation, population growth and the call for sustainable development, there is a need for a more circumspect and responsible adaptation to strategies of resilience. Humans must learn to act and interact in concert with nature. We have the innate need for drinking water and therefore instinctively reach out to satisfy the demand for this fluid that constitutes at least $65 \%$ of our body mass. For humans to understand their own history, as well as that of nature, could create a consciousness of becoming more sensitive to the deeper origins of our emergence on this planet. After all, our emergence as the human race, what we have become and how we have learnt - with varying degrees of success - to co-exist in social groupings, is intricately interwoven with the natural world. Our aim should be to understand the role water played in former times. It has to potential to inform our current understanding of issues of water security in times of scarcity in the present and in the future. Water is representative of a unique compass enabling us to comprehend a social system in which we are unable to comprehend at all times the significance of a complex, inclusive ecology. ${ }^{101}$

\footnotetext{
99. RA Makkreel, "Hermeneutics" in A Tucker (ed.), A companion to the philosophy of bistory and historiography (Wiley Blackwell, Malden, 2009), pp. 532.

100. D Christian, Maps of time: an introduction to big history (University of California Press, Berkeley, 2011), pp. 207-237.

101. B Castellani and FW Hafferty, Sociology and complexity science: a new field of inquiry (Springer, Heidelberg, 2009), pp. 175-7.
}

TD, 11(2), November 2015, Special edition, pp. 104-121. 